NOTES

\title{
Synthesis of Poly(lactic acid) from the Salts of 2-Halogenopropanoic Acid
}

\author{
Fumihiko Akutsu, Mari InOKI, Takeshi Morita, Yasuyuki TaKaO, \\ Kiyoshi NarUCHI, and Yoshiaki YamaguCHI* \\ Department of Applied Chemistry, Faculty of Engineering, Chiba University, \\ Yayoi-cho 1-33, Inage-ku, Chiba-shi 263, Japan \\ *Musashino Chemical Laboratory, Ltd., Tokyo Laboratory, \\ 16-2, Miyamae 1-chome, Suginami-ku, Tokyo 168, Japan
}

(Received April 14, 1995)

\begin{abstract}
KEY WORDS Solid State / Thermal Reaction / Polycondensation / Poly(lactic acid) / Salts of 2-Bromopropanoic Acid / Salts of 2Chloropropanoic Acid/
\end{abstract}

We previously investigated ${ }^{1}$ that the thermal reactions of salts of 2-bromo- $n$-butyric acid (BrBA) produce polyester having medium molecular weight $(3500-3800)$ or oligoesters including dimers and trimers by stepwise reactions. The reactivity of the monomeric salts was highly dependent on the crystallinity.

In the present study, we introduced the salts of 2-bromopropanoic acid (BrPA) or those of 2-chloropropanoic acid (ClPA) into the thermal reactions in the solid state as monomers, expecting the formation of poly(lactic acid) which is well known as a biodegradable polymer. ${ }^{2-4}$ As a result, poly(lactic acid) of which the number-average molecular weight $\left(\bar{M}_{n}\right)$ was three times as high as that of a polyester obtained from the salt of BrBA or oligo(lactic acid) including dimers and trimers was obtained. In addition, the reaction mechanism of the thermal reactions was investigated. Bezzi reported the thermal reaction of sodium 2-bromopropanoate. ${ }^{5,6}$ Kozorovitskii reported the formation of poly(lactic acid) by the thermal reaction of a mixture of sodium hydroxide and 2-chloropropanoic acid. ${ }^{7}$ Ono et al. reported that the reactions of alkali and alkaline earth 2-halogenopropanoates in ace- tone under pressure produce lactide which is the cyclized dimer. ${ }^{8}$ However, neither reaction mechanism nor identification of the obtained products has been reported.

\section{EXPERIMENTAL}

2-Bromopropanoic acid and racemic $(R S)$ $( \pm)$-2-chloropropanoic acid were obtained from Tokyo Kasei Kogyo Co., Ltd. (S)-(-)2-Chloropropanoic acid was obtained from Aldrich Chemical Co.

The monomeric salts were prepared by neutralizing the carboxylic acids with metal hydroxide in methanol according to the meth$\mathrm{od}^{1}$ reported previously. Anhydrous sodium (Na-BrPA), potassium (K-BrPA), magnesium (Mg-BrPA), calcium (Ca-BrPA), and barium (Ba-BrPA) 2-bromopropanoates and sodium 2-chloropropanoates (Na-ClPAs) were used as monomers.

Anal.

$\mathrm{Na}-\mathrm{BrPA}$ : Calcd for $\mathrm{C}_{3} \mathrm{H}_{4} \mathrm{O}_{2} \mathrm{BrNa}(175.0)$ : C, $20.59 \%$; H, 2.30\%. Found: C, $20.36 \% ; \mathrm{H}$, $2.23 \%$.

K-BrPA: Calcd for $\mathrm{C}_{3} \mathrm{H}_{4} \mathrm{O}_{2} \mathrm{BrK}$ (191.1): C, $18.86 \%$; H, 2.11\%. Found: C, $18.73 \% ; \mathrm{H}$, 
$1.95 \%$.

Mg-BrPA: Calcd for $\left(\mathrm{C}_{3} \mathrm{H}_{4} \mathrm{O}_{2} \mathrm{Br}\right)_{2} \mathrm{Mg}$ (328.2): C, 21.95\%; H, 2.46\%. Found: C, $21.49 \%$; H, $2.96 \%$.

Ca-BrPA: Calcd for $\left(\mathrm{C}_{3} \mathrm{H}_{4} \mathrm{O}_{2} \mathrm{Br}\right)_{2} \mathrm{Ca}$ (344.0): C, 20.95\%; H, 2.34\%. Found: C, $20.47 \%$; H, 2.65\%.

Ba-BrPA: Calcd for $\left(\mathrm{C}_{3} \mathrm{H}_{4} \mathrm{O}_{2} \mathrm{Br}\right)_{2} \mathrm{Ba}$ (441.3): C, $16.33 \%$; H, 1.83\%. Found: C, $16.20 \% ; \mathrm{H}, 2.03 \%$.

$(R S)$-Na-ClPA: Calcd for $\mathrm{C}_{3} \mathrm{H}_{4} \mathrm{O}_{2} \mathrm{ClNa}$ (130.5): C, $27.60 \%$; H, 3.09\%. Found: C, $27.47 \%$; H, $2.93 \%$.

$(S)$-Na-ClPA: Calcd for $\mathrm{C}_{3} \mathrm{H}_{4} \mathrm{O}_{2} \mathrm{ClNa}$ (130.5): C, 27.60\%; H, 3.09\%. Found: C, $27.47 \% ; \mathrm{H}, 3.25 \%$.

The monomeric salt $(1.5 \mathrm{~g})$ was put into a Pyrex tube, and heated in an oil bath under reduced pressure for $2 \mathrm{~h}$. The reaction mixture, except those from the sodium salts and potassium salt, was dissolved in water, acidified with hydrochloric acid, and then extracted with ether. The extracts were treated with diazomethane in ether. The methyl esters from Ba-BrPA $\left(130^{\circ} \mathrm{C}\right)$ were separated by fractional distillation under reduced pressure: the first fraction, $50-51^{\circ} \mathrm{C}$ at $25 \mathrm{mmHg}$; second fraction, $82-84^{\circ} \mathrm{C}$ at $4 \mathrm{mmHg}$; third fraction, $131-133^{\circ} \mathrm{C}$ at $4 \mathrm{mmHg}$. Spectroscopic data of second fraction and third fraction are as follows.

Second fraction (1): ${ }^{1} \mathrm{H}$ NMR $(500 \mathrm{MHz}$, $\left.\mathrm{CDCl}_{3}\right): \delta=1.537\left(\mathrm{~d} ; 3 \mathrm{H},-\mathrm{C}_{3}\right), 1.545(\mathrm{~d} ; 3 \mathrm{H}$, $\left.-\mathrm{CH}_{3}\right), 1.864\left(\mathrm{~d} ; 3 \mathrm{H},-\mathrm{CH}_{3}\right), 1.871(\mathrm{~d} ; 3 \mathrm{H}$, $\left.-\mathrm{CH}_{3}\right), 3.764\left(\mathrm{~s} ; 3 \mathrm{H},-\mathrm{COOC} \underline{H}_{3}\right), 3.769(\mathrm{~s} ; 3 \mathrm{H}$, $\left.-{ }_{-}{ }^{-O O C} \underline{H}_{3}\right), 4.422$ (q; $\left.1 \mathrm{H}, \overline{\mathrm{C}} \underline{\mathrm{HBr}}\right), 4.457$ (q; $1 \mathrm{H}, \mathrm{C} \underline{\mathrm{HBr}}$ ), 5.157 (q; 2H, $\underline{\mathrm{HCOOCH}}_{3}$ ).

${ }^{13} \mathrm{C}$ NMR $\left(125 \mathrm{MHz}, \mathrm{CDCl}_{3}\right): \delta=16.70$ $\left(\mathrm{CH}_{3}\right), 21.53\left(\mathrm{CH}_{3}\right), 21.58\left(\mathrm{CH}_{3}\right), \quad 39.37$ $(\mathrm{CHBr}), 39.47(\mathrm{CHBr}), 52.48\left(-\mathrm{COOCH}_{3}\right)$, $69.76\left(\mathrm{CHCOOCH}_{3}\right), 169.50(\mathrm{C}=\mathrm{O}), 169.72$ $(\mathrm{C}=\mathrm{O}), 170.51(\mathrm{C}=\mathrm{O}), 170.64(\mathrm{C}=\mathrm{O})$.

IR (Neat): $1744(\mathrm{C}=\mathrm{O}), 1222,1162(\mathrm{C}-\mathrm{O})$ $\mathrm{cm}^{-1}$.

Mass (EI): $m / z 209\left(\mathrm{M}+2-\mathrm{OCH}_{3}\right), 207$ $\left(\mathrm{M}-\mathrm{OCH}_{3}\right), \quad 181\left(\mathrm{M}+2-\mathrm{COOCH}_{3}\right), \quad 179$
$\left(\mathrm{M}-\mathrm{COOCH}_{3}\right), 137\left(\mathrm{M}+2-\mathrm{C}_{4} \mathrm{H}_{7} \mathrm{O}_{3}\right), 135$

$\left(\mathrm{M}-\mathrm{C}_{4} \mathrm{H}_{7} \mathrm{O}_{3}\right), \quad 109\left(\mathrm{M}+2-\mathrm{C}_{5} \mathrm{H}_{7} \mathrm{O}_{4}\right), \quad 107$

$\left(\mathrm{M}-\mathrm{C}_{5} \mathrm{H}_{7} \mathrm{O}_{4}\right)$.

Third fraction (2): ${ }^{1} \mathrm{H}$ NMR $(500 \mathrm{MHz}$, $\left.\mathrm{CDCl}_{3}\right): \delta=1.500-1.538\left(\mathrm{~m} ; 12 \mathrm{H},-\mathrm{CH}_{3}\right)$, $1.581\left(\mathrm{~d} ; 3 \mathrm{H},-\mathrm{CH}_{3}\right), 1.591\left(\mathrm{~d} ; 3 \mathrm{H},-\mathrm{CH}_{3}\right)$, $1.613\left(\mathrm{~d} ; 3 \mathrm{H},-\mathrm{CH}_{3}\right), 1.617\left(\mathrm{~d} ; 3 \mathrm{H},-\underline{\mathrm{CH}}_{3}\right)$, $1.854\left(\mathrm{~d} ; 3 \mathrm{H},-\mathrm{C}_{3}\right), 1.859\left(\mathrm{~d} ; 3 \mathrm{H},-\underline{\mathrm{C}}_{3}\right)$, $1.864\left(\mathrm{~d} ; 3 \mathrm{H},-\mathrm{CH}_{3}\right), 1.870\left(\mathrm{~d} ; 3 \mathrm{H},-\mathrm{CH}_{3}\right)$, $3.748\left(\mathrm{~s} ; 6 \mathrm{H},-\mathrm{COOCH}_{3}\right), 3.758(\mathrm{~s} ; 6 \mathrm{H}$, $\left.-\mathrm{COOCH}_{3}\right), 4.401-4.479(\mathrm{~m} ; 4 \mathrm{H},-\mathrm{CHBr}-$ $\left.\mathrm{CH}_{3}\right), 5.142-5.244(\mathrm{~m} ; 8 \mathrm{H},-\mathrm{COOCH}-)$.

${ }^{13} \mathrm{C}$ NMR $\left(125 \mathrm{MHz}, \mathrm{CDCl}_{3}\right): \bar{\delta}=16.52$ $\left(-\mathrm{CH}_{3}\right), 16.56\left(-\mathrm{CH}_{3}\right), 16.59\left(-\mathrm{CH}_{3}\right), 16.64$ $\left(-\mathrm{CH}_{3}\right), 16.79\left(-\mathrm{CH}_{3}\right), 16.83\left(-\mathrm{CH}_{3}\right), 21.54$ $\left(-\mathrm{CH}_{3}\right), 21.60\left(-\mathrm{CH}_{3}\right), 39.25(-\mathrm{CHBr}-), 39.30$ $(-\mathrm{C} \underline{\mathrm{HBr}}-), 39.41(-\mathrm{C} \underline{\mathrm{HBr}}-), 52.43\left(-\mathrm{COOCH}_{3}\right)$, $52.48\left(-\mathrm{COOCH}_{3}\right), 69.26(-\mathrm{COOC} \mathrm{H}-), 69.36$ $(-\mathrm{COO} \underline{\mathrm{CH}}-), \quad 69.50 \quad(-\mathrm{COO} \underline{\mathrm{H}}-), \quad 69.62$ $(-\mathrm{COO} \underline{\mathrm{C}} \mathrm{H}-), \quad 69.70 \quad(-\mathrm{COO} \underline{\mathrm{C}} \mathrm{H}-), \quad 69.76$ $(-\mathrm{COO} \underline{\mathrm{C}}-), 169.36(\mathrm{C}=\mathrm{O}), 169.43(\mathrm{C}=\mathrm{O})$, $169.50(\mathrm{C}=\mathrm{O}), 169.53(\mathrm{C}=\mathrm{O}), 169.69(\mathrm{C}=\mathrm{O})$, $169.79(\mathrm{C}=\mathrm{O}), 170.37(\mathrm{C}=\mathrm{O}), 170.42(\mathrm{C}=\mathrm{O})$, $170.58(\mathrm{C}=\mathrm{O})$.

IR (Neat): 1756(C=O), 1214, $1160(\mathrm{C}-\mathrm{O})$ $\mathrm{cm}^{-1}$.

Mass $(\mathrm{FAB}+): m / z 313\left(\mathrm{MH}^{+}+2\right), 311$ $\left(\mathrm{MH}^{+}\right), 281\left(\mathrm{M}+2-\mathrm{OCH}_{3}\right), 279(\mathrm{M}-$ $\left.\mathrm{OCH}_{3}\right), 209\left(\mathrm{M}+2-\mathrm{C}_{4} \mathrm{H}_{7} \mathrm{O}_{3}\right), 207(\mathrm{M}-$ $\left.\mathrm{C}_{4} \mathrm{H}_{7} \mathrm{O}_{3}\right), 181\left(\mathrm{M}+2-\mathrm{C}_{5} \mathrm{H}_{7} \mathrm{O}_{4}\right), 179(\mathrm{M}-$ $\mathrm{C}_{5} \mathrm{H}_{7} \mathrm{O}_{4}$ ).

The reaction mixtures obtained from the sodium salts and the potassium salt were suspended in acetone, acidified with hydrochloric acid, filtrated to remove sodium bromide or potassium bromide, and poured into water. The precipitates were filtrated with a glass filter, washed with water, and dried under reduced pressure. The obtained polymers were freeze-dried from benzene solution. The molecular weight was determined by gel permeation chromatography (GPC).

Poly(lactic acid): ${ }^{1} \mathrm{H}$ NMR $(500 \mathrm{MHz}$, $\left.\mathrm{CDCl}_{3}\right): \delta=1.529-1.588\left(\mathrm{~m} ; 3 \mathrm{H},-\mathrm{C}_{3}\right)$, $5.138-5.229\left(\mathrm{~m} ; 1 \mathrm{H},-\mathrm{C} \underline{\mathrm{H}}\left(\mathrm{CH}_{3}\right) \mathrm{COO}-\right)$.

${ }^{13} \mathrm{C}$ NMR $\left(125 \mathrm{MHz}, \mathrm{CDCl}_{3}\right): \delta=16.64$ 
$\left(-\mathrm{CH}_{3}\right), 16.71\left(-\mathrm{CH}_{3}\right), 16.75\left(-\mathrm{CH}_{3}\right), 69.00-$ $69.41 \quad\left(-\mathrm{CH}\left(\mathrm{CH}_{3}\right) \mathrm{COO}-\right), \quad 169.14-169.92$ $(\mathrm{C}=\mathrm{O})$.

IR (KBr): $1754(\mathrm{C}=\mathrm{O}), 1190,1090(\mathrm{C}-\mathrm{O})$ $\mathrm{cm}^{-1}$.

Anal. Calcd for $\left(\mathrm{C}_{3} \mathrm{H}_{4} \mathrm{O}_{2}\right)_{n}(72.06)_{n}$ : C, $50.00 \%$; H, 5.59\%. Found: C, $49.88 \%$; H, $5.52 \%$.

The hydrolysis of poly(lactic acid) obtained from $(S)-(-)$-Na-ClPA was performed as follows. The polyester $(0.5 \mathrm{~g})$ was dissolved in tetrahydrofuran $(20 \mathrm{ml})$ and conc $\mathrm{HCl}(10 \mathrm{ml})$ was added. The mixture was stirred at $40^{\circ} \mathrm{C}$ for 1day, and then extracted with ether three portions. After the removal of ether with a rotary evaporator, the obtained yellow oil was treated with diazomethane in ether, and distilled under reduced pressure $\left(70-73^{\circ} \mathrm{C} /\right.$ $20 \mathrm{mmHg}$ ). An optical rotation of the distillate was measured $\left([\alpha]_{\mathrm{D}}^{25}=-2.38^{\circ}\right)$.

\section{Measurement}

IR spectra were recorded on a Hitachi 270-30 spectrophotometer. NMR spectra were obtained with FT-NMR spectrometer (JEOL JNM-GSX500). GPC-measurements were performed on a Toyo Soda HLC-802UR high speed liquid chromatography using polystyrene gel columns (solvent, tetrahydrofuran; calibration, poly(methyl methacrylate) standards). Wide angle X-ray diffraction patterns were obtained for specimens on Rigaku Denki XG $\mathrm{X}$-ray diffraction apparatus with $\mathrm{Cu}-K_{\alpha}$ radiation $(35 \mathrm{kV}, 20 \mathrm{~mA})$. For gas chromatography (GC) measurements, a Hitachi 263-50 apparatus was used under the followimg conditions: column packing, Silicone SE-30 $(3 \mathrm{~mm} \times 2 \mathrm{~m})$; column temperature, range of $50-250^{\circ} \mathrm{C}$; heating rate, $10 \mathrm{~K} \mathrm{~min}^{-1}$; carrier gas, nitrogen; gas flow, $30 \mathrm{ml} \mathrm{min}^{-1}$; internal standard, dimethyl succinate. The mass spectra were recorded on JEOL JMS-HX110 (FAB) and Hitachi M-60 (EI) mass spectrometers. Optical rotations were measured at $25^{\circ} \mathrm{C}$ using a Horiba SEPA-300 polarimeter (solvent, chloroform; concentration, $10 \mathrm{gl}^{-1}$ ).

\section{RESULTS AND DISCUSSION}

Thermal reactions of $\mathrm{Mg}-, \mathrm{Ca}-$, and Ba-BrPA were performed at 130 and $150^{\circ} \mathrm{C}$ for $2 \mathrm{~h}$. The products were acidified and subsequently converted to methyl esters using diazomethane. The gas chromatogram of the esters from $\mathrm{Ba}-\mathrm{BrPA}\left(130^{\circ} \mathrm{C}\right)$ showed six peaks, the sixth being extremely broad. The esters were fractionally distilled under reduced pressure into three fractions. The first fraction corresponding to the first peak of the gas chromatogram was the methyl ester of the monomer as shown by the coinjection method. The second and third fractions corresponding to the second and third peaks were identified by spectroscopic data as methyl esters of dimers (1) and those of trimers (2), respectively. The NMR spectra of the methyl esters of the dimers suggest the presence of two diastereoisomers, of which the ratio was $1: 1$. Those of the trimers suggest the presence of at least four diastereoisomers. The other fractions had boiling points so high that they could not be separated, but the fourth and fifth peaks were presumed as the methyl esters of tetramers and those of pentamers from the above results. The yields of the dimers, trimers, tetramers, and pentamers were determined by GC using dimethyl succinate as an internal standard. The gas chromatogram of the product from Ba-BrPA $\left(150^{\circ} \mathrm{C}\right)$ shows only the sixth broad peak. Spectroscopic data of the product indicated the formation of oligo(lactic acid), of which $\bar{M}_{n}$ determined by GPC was 1300 . Because the yield of the sixth broad peak corresponding to oligo(lactic acid) could not be determined by GC, that was calculated based on the "yield" of the recovered monomer and those of the dimers to the tetramers. These results are summarized in Table I.

Thermal reactions of Na- and K-BrPA were conducted at 120,130 , and $150^{\circ} \mathrm{C}$. The products were not soluble in water. Therefore, those were suspended in acetone and acidified. The results are summarized in Table II. $\bar{M}_{n}$ of the 
Table I. Thermal reactions of alkaline earth 2-bromo-propanoates in the solid state ${ }^{a}$

\begin{tabular}{ccccccc}
\hline \multirow{2}{*}{$\begin{array}{c}\text { Metallic } \\
\text { salt }\end{array}$} & $\begin{array}{c}\text { Heating } \\
\text { temp } /{ }^{\circ} \mathrm{C}\end{array}$ & \multicolumn{5}{c}{ Yield/\% } \\
\cline { 3 - 7 } & & Dimer $^{\mathrm{b}}$ & Trimer $^{\mathrm{b}}$ & Tetramer $^{\mathrm{b}}$ & Pentamer $^{\mathrm{b}}$ & Oligomer $^{\mathrm{c}}$ \\
\hline $\mathrm{Mg}$ & 130 & 6.7 & $-^{\mathrm{d}}$ & - & - & - \\
$\mathrm{Mg}$ & 150 & 17.1 & 0.8 & - & - & - \\
$\mathrm{Ca}$ & 130 & 6.6 & 0.7 & - & - & - \\
$\mathrm{Ca}$ & 150 & 13.8 & 7.7 & 2.6 & 0.8 & - \\
$\mathrm{Ba}$ & 130 & 4.0 & 8.1 & 9.5 & 8.6 & 69.1 \\
$\mathrm{Ba}$ & 150 & - & - & - & - & 88.5 \\
\hline
\end{tabular}

${ }^{\mathrm{a}}$ Heating time, $2 \mathrm{~h} .{ }^{\mathrm{b}}$ Determined by GC using dimethyl succinate as internal standard. ${ }^{\mathrm{c}}$ Degree of polymerization larger than six. Calculated from the yields of the other products. ${ }^{\text {d }}$, , trace.

Table II. Thermal reactions of sodium and potassium 2-bromo-propanoates in the solid state ${ }^{\mathrm{a}}$

\begin{tabular}{ccccc}
\hline & & \multicolumn{3}{c}{ Polymer } \\
\cline { 3 - 5 } $\begin{array}{c}\text { Metallic } \\
\text { salt }\end{array}$ & $\begin{array}{c}\text { Heating } \\
\text { temp/ } \\
{ }^{\circ} \mathrm{C}\end{array}$ & Yield/\% & $10^{-3} \times \bar{M}_{n}{ }^{\mathrm{b}}$ & $\begin{array}{c}\text { Ratio of } \\
\bar{M}_{w} / \bar{M}_{n}{ }^{\mathrm{c}}\end{array}$ \\
\cline { 3 - 5 } & & & 1.8 & 1.4 \\
$\mathrm{Na}$ & 120 & 88.2 & 5.2 & 2.1 \\
$\mathrm{Na}$ & 130 & 90.0 & 11.5 & 2.4 \\
$\mathrm{Na}$ & 150 & 85.6 & & \\
$\mathrm{~K}$ & 120 & 77.8 & 2.1 & 2.2 \\
$\mathrm{~K}$ & 130 & 78.8 & 5.5 & 1.6 \\
$\mathrm{~K}$ & 150 & 83.7 & 6.1 & 2.0
\end{tabular}

${ }^{a}$ Heating time, 2 h. ${ }^{b}$ Number-average molecular weight determined by GPC. ${ }^{\mathrm{c}}$ Weight-average molecular weight determined by GPC.

product from $\mathrm{Na}-\mathrm{BrPA}\left(150^{\circ} \mathrm{C}\right)$ was 11500 , which is $c a$. three times as high as that of a polyester obtained by a similar reaction of Na-BrBA ${ }^{1}\left(\bar{M}_{n}, 3800\right)$ previously reported. The spectroscopic data and elemental analysis of the polymers from $\mathrm{Na}-\mathrm{BrPA}$ and from $\mathrm{K}$ BrPA confirmed the formation of poly(lactic acid). The yield and $\bar{M}_{n}$ of poly(lactic acid) from $\mathrm{Na}-\mathrm{BrPA}\left(130^{\circ} \mathrm{C}\right)$ are shown as functions of reaction time in Figure 1. The yield was almost quantitative after 1 h. $\bar{M}_{n}$ increased with time, and reached 9700 after $4 \mathrm{~h}$. The thermal reactions were found to proceed in a stepwise

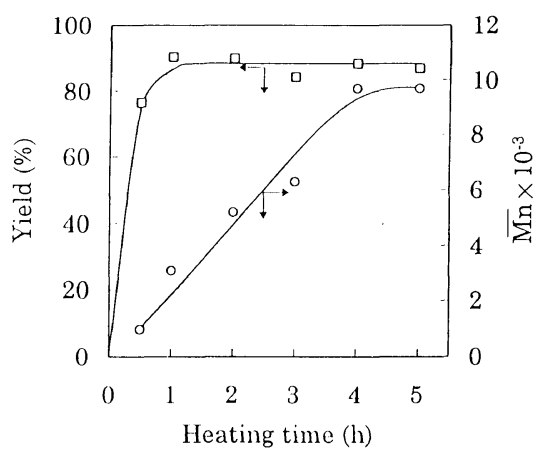

Figure 1. Thermal reactions of Na-BrPA in the solid state at $130^{\circ} \mathrm{C}$.

manner.

The X-ray diffraction patterns show that $\mathrm{Na}-$, and K-BrPA form crystalline salts and that $\mathrm{Mg}-\mathrm{Ca}-$, and $\mathrm{Ba}-\mathrm{BrPA}$ form amorphous salts. Thus, the crystalline monomeric salts have high reactivity and the amorphous monomeric salts, low reactivity. It is known that, in the solid-state polymerization, the difference in the reactivity of the monomeric salts is due to the difference in their crystallinity and crystal structures. ${ }^{9,10}$ We found that the crystallinity of the salts of methacrylic acid affects their reactivity and the products of the solid-state polymerization. ${ }^{11}$ The reactivity of the salts of BrPA was found to be also influenced by their crystallinity. The higher 
Synthesis of Poly(lactic acid)

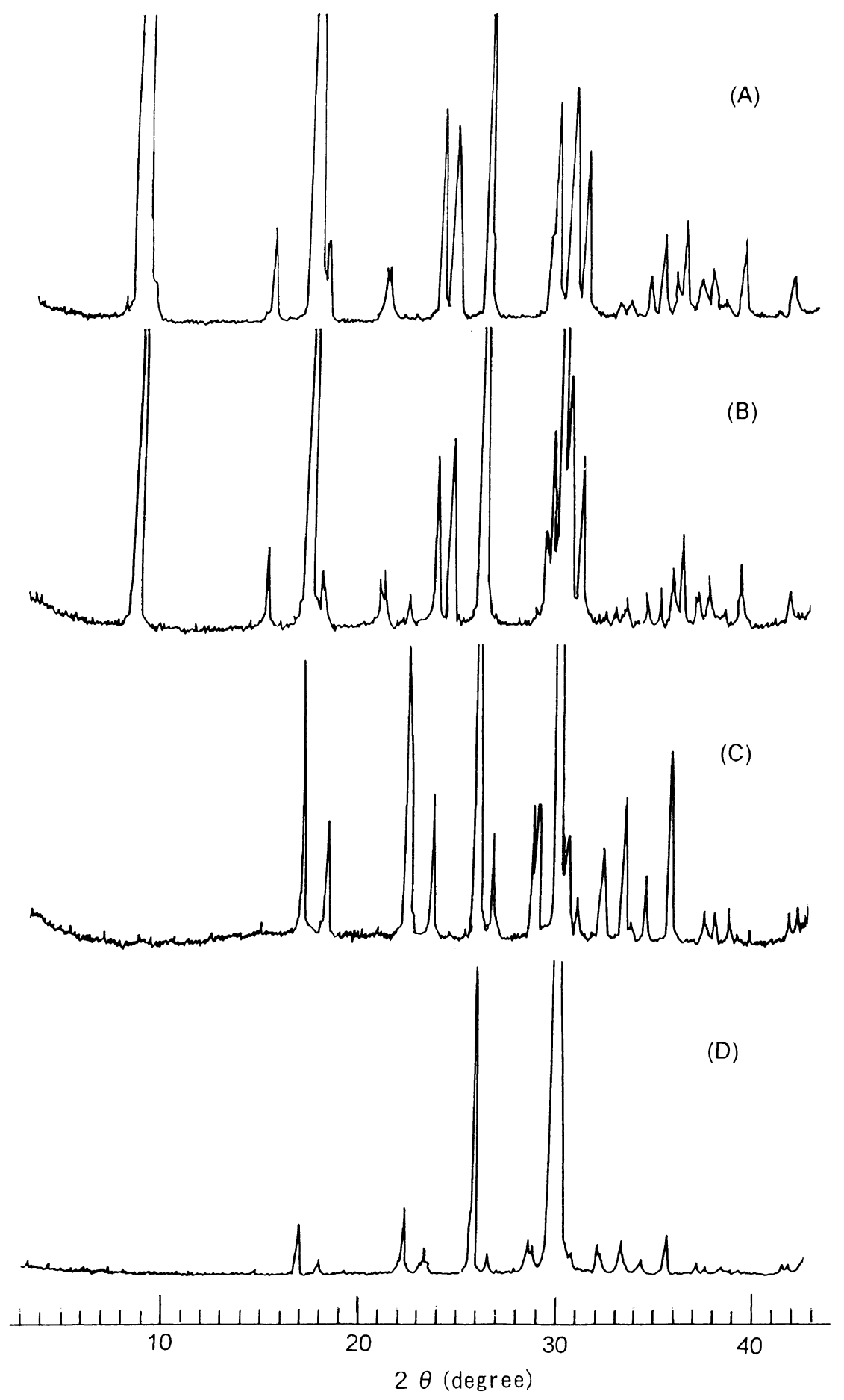

Figure 2. X-Ray diffraction patterns of heated Na-BrPA and of sodium bromide: (A), the starting material; (B), the salt heated for $20 \mathrm{~min}$; (C), the salt heated for $1 \mathrm{~h}$; (D), sodium bromide. 
Table III. Thermal reactions of sodium 2-bromo- and 2-chloropropanoates in the solid state

\begin{tabular}{|c|c|c|c|c|}
\hline \multirow{2}{*}{ Metallic salt } & \multicolumn{2}{|c|}{ Polymer } & \multicolumn{2}{|c|}{$[\alpha]_{\mathrm{D}}^{25 \mathrm{c}}$} \\
\hline & Yield $/ \%$ & $10^{-3} \times M_{n}^{b}$ & Monomer $^{d}$ & $\begin{array}{l}\text { Hydrolyzate of } \\
\text { the polyester }\end{array}$ \\
\hline $\mathrm{Na}-\mathrm{BrPA}$ & 85.6 & 11.5 & & \\
\hline$(R S)-( \pm)-\mathrm{Na}-\mathrm{ClPA}$ & 90.1 & 2.2 & & \\
\hline$(S)-(-)-\mathrm{Na}-\mathrm{ClPA}$ & 83.8 & 2.3 & $-23.82(88.8)$ & $-2.38(28.8)$ \\
\hline
\end{tabular}

${ }^{a}$ Heating time, $2 \mathrm{~h}$; reaction temperature, $150^{\circ} \mathrm{C}$. ${ }^{\mathrm{b}}$ Number-average molecular weight determined by GPC. ${ }^{\mathrm{c}} \mathrm{Optical}$ rotation measured in chloroform at $25^{\circ} \mathrm{C}$. Data in parenthese are optical purities in $\%$. ${ }^{\mathrm{d}}$ Measured after esterification using diazomethane.

reactivity of $\mathrm{Na}-\mathrm{BrPA}$ than that of $\mathrm{Na}-\mathrm{BrBA}$ was attributed to the more favorable arrangements of $\mathrm{Na}-\mathrm{BrPA}$ in the crystal lattice and to the relaxation of steric hindrance caused by the side chains. In the thermal reaction of $\mathrm{Na}-\mathrm{BrPA}$ $\left(120^{\circ} \mathrm{C}\right)$, the $\mathrm{X}$-ray diffraction patterns as functions of reaction time were indicated in Figure 2. After $20 \mathrm{~min}$ (yield, $35.4 \% ; \bar{M}_{n}, 600$ ), the X-ray diffraction pattern showed a peak of the monomeric salt with that of sodium bromide eliminated by the polycondensation. After $1 \mathrm{~h}$ (yield, $81.8 \% ; \bar{M}_{n}, 1500$ ), the X-ray diffraction pattern showed only a peak of sodium bromide. As the monomeric salt was consumed by the polycondensation and poly(lactic acid) produced became amorphous, a peak of the monomeric salt faded and the only peak of sodium bromide was shown in process of the reaction.

The results on the thermal reactions $\left(150^{\circ} \mathrm{C}\right.$, $2 \mathrm{~h}$ ) of Na-ClPAs are summarized in Table III. Poly(lactic acid) was also obtained quantitatively from racemic $(R S)-( \pm)-\mathrm{Na}-\mathrm{ClPA}$, but $\bar{M}_{n}$ of the polyester, of which the value was 2200 , was lower than that from $\mathrm{Na}-\mathrm{BrPA}$ (11500). This lowering was attributed to the lower reactivity of the chloro-group. The thermal reaction of chiral $(S)-(-)$-Na-ClPA was carried out on the same condition. As a result, poly(lactic acid), of which $\bar{M}_{n}$ was 2300 , was obtained. The X-ray diffraction patterns of the chiral salt and of the racemic salt show that those form crystalline salts, but the X-ray diffraction pattern of the chiral salt was found

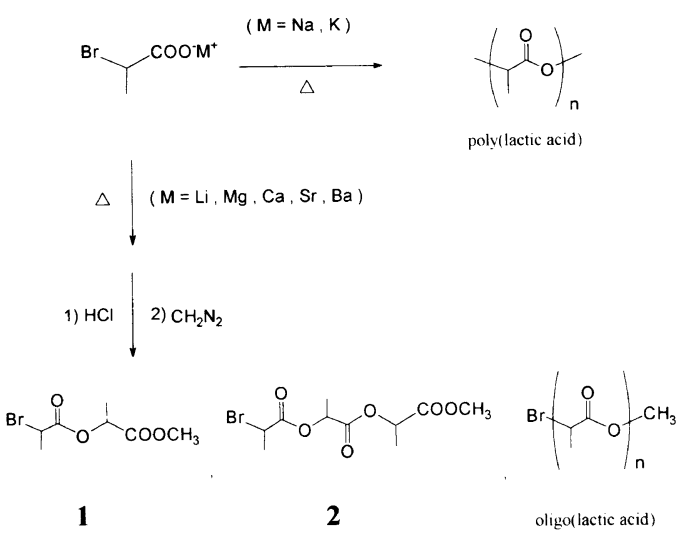

to be different from that of the racemic salt. The polyester was hydrolyzed, esterified using diazomethane, and then the optical rotation was measured. The optical purity of the methyl ester of monomeric $(S)-(-)$-Na-ClPA was $88.8 \%$, but that of the methyl ester of the hydrolyzate of the polyester lowered $(28.8 \%)$, that is, the condensation process was involved in racemization. This suggested that the polycondensation of Na-ClPA mainly proceeds in a reaction mechanism such as a $S_{\mathrm{N}} 1$ reaction.

It was concluded that the thermal reactions of alkali and alkaline earth 2-bromopropanoates in the solid state produced poly(lactic acid) or oligo(lactic acid) including dimers and trimers by stepwise reactions, and that the crystallinity of the monomeric salts influenced the reactivity. The reactivity of Na-BrPA was higher than that of Na-BrBA. Poly(lactic acid) was also synthesized from Na-ClPAs, but $\bar{M}_{n}$ s 
of the obtained polyesters were found to be lower $\left(\bar{M}_{n}, 2200-2300\right)$ than that from Na-BrPA $\left(\bar{M}_{n}, 11500\right)$. The polycondensation was found to proceed mainly in a reaction mechanism such as a $S_{\mathrm{N}} 1$ reaction.

Acknowledgments. The authors thank Mr. Tadao Kuramochi and Ms. Hiroko Seki of the Chemical Analysis Center, Chiba University, for carrying out the elemental analysis and recording the NMR and mass spectra.

\section{REFERENCES}

1. Y. Takao, Y. Kasashima, M. Inoki, F. Akutsu, K. Naruchi, and Y. Yamaguchi, Polym. J., in press.

2. D. K. Gilding and A. M. Reed, Polymer, 20, 1459
(1979).

3. A. M. Reed and D. K. Gilding, Polymer, 22, 494 (1981).

4. K. J. Zhu, L. Xiangzhou, and Y. Shilin, J. Polym. Sci., C, Polym. Lett., 24, 331 (1986).

5. S. Bezzi, Atti Mem. Accad. Sci., Padova, 55, 85 (1939); Chem. Abstr., 36, 5690 (1942).

6. S. Bezzi, Gazz. Chim. Ital., 79, 219 (1949); Chem. Abstr., 44, 1022e (1950).

7. A. Ya. Kozorovitskii and B. P. Manannikov, U.S.S.R. Patent, SU 852889 (1981); Chem. Abstr., 96, 35891a (1982).

8. H. Ono and H. Phala, Jpn. Kokai Tokkyo Koho, JP 02-28173 (1990); Eur. Patent, Appl., EP 339882 (1989); Chem. Abstr., 112, 216941m (1990).

9. H. Morawetz and I. D. Rubin, J. Polym. Sci., 57, 669 (1962).

10. J. B. Lando and H. Morawetz, J. Polym. Sci., C, Polym. Symp., 4, 789 (1963).

11. K. Naruchi and M. Miura, Polymer, 22, 1716 (1981). 